\title{
Influence of food, storage temperature, and time on the extracorporeal viability of ruminal fluid of cattle
}

\section{Influência da alimentação, temperatura e tempo de estocagem sobre a viabilidade extracorpórea do fluido ruminal de bovinos}

\author{
Camila Cecilia Martin ${ }^{1 *}$; Ayrton Rodrigo Hilgert ${ }^{1}$; \\ Erica Cristina Bueno do Prado Guirro ${ }^{2}$
}

\begin{abstract}
Rumen fluid obtained from slaughter houses is sometimes used for transfaunation. In this study, we evaluated the ruminal fluid of cattle fed on pasture or pasture and concentrate and slaughtered recently. The rumen fluid samples were stored in a water bath, at ambient temperature, cooled, or frozen and subjected to physical, chemical, and microbiological evaluation for $24 \mathrm{~h}$. The color, consistency, and odor changed primarily in the cooled samples, followed by the ambient temperature and water bath samples. The $\mathrm{pH}$ of fresh ruminal fluid was 7.5 in the pasture group and 6.4 in the pasture and concentrate group. The methylene blue reduction time of the fresh ruminal fluid was $2.35 \mathrm{~min}$ in the pasture group and $1.86 \mathrm{~min}$ in the pasture and concentrate group; the best values were observed in the water bath group. The chloride content was $15.7 \mathrm{mEq} / 1$ in the pasture group and $16.3 \pm 3.6 \mathrm{mEq} / \mathrm{l}$ in the pasture and concentrate group. A predominance of gram-negative bacteria was observed. The concentration of protozoa was 51.5 in the pasture group and $47.5 \times 10^{4} / \mathrm{ml}$ in the pasture and concentrate group, with a slight predominance of small protozoa; motility was better in the water bath samples than in the ambient temperature, cooled, and frozen samples. The viability of ruminal fluid collected from freshly slaughtered cattle was influenced by food provided in vivo; however, changes as a function of time and storage temperature were more remarkable. The rumen fluid was viable for up to $9 \mathrm{~h}$ when stored in the water bath $\left(38^{\circ} \mathrm{C}\right)$ and $2 \mathrm{~h}$ at ambient temperature, and it was observed to be nonviable when subjected to cooling or freezing.
\end{abstract}

Key words: Microbiota. Rumen. Ruminal fluid. Storage. Transfaunation.

Resumo

Algumas vezes é necessário utilizar fluido ruminal obtido em abatedouros para transfaunação. Este estudo avaliou o fluido ruminal de bovinos recém abatidos alimentados in vivo com pasto ou pasto e concentrado estocados sob banho-maria, temperatura ambiente, refrigerado ou congelado submetidos à análise física, química e microbiológica por 24 horas. A cor, consistência e odor se alteraram primeiramente em refrigeração, seguido por temperatura ambiente e banho-maria. A fresco (TF) o pH foi de 7,5 no grupo pasto e 6,4 no grupo pasto e concentrado. O tempo de redução do azul de metileno a fresco foi $2.35 \mathrm{~min}$ no grupo pasto e 1.86 no grupo que recebeu pasto e concentrado, os melhores valores foram encontrados no grupo banho-maria. A concentração de cloreto no grupo pasto foi 15,7

\footnotetext{
Discentes, Curso de Doutorado, Programa de Pós-Graduação em Clínica Médica da Faculdade de Medicina Veterinária e Zootecnia, Universidade de São Paulo, USP, São Paulo, SP, Brasil. E-mail: camilacmartin@gmail.com; ayrton.hilgert@gmail. com

2 Prof ${ }^{a}$, Universidade Federal do Paraná, UFPR, Campus Palotina, Palotina, PR, Brasil. E-mail: prof.erica.guirro@gmail.com

* Author for correspondence
} 
e no grupo pasto e concentrado foi $16,3 \mathrm{mEq} / \mathrm{L}$. Em relação às bactérias houve predomínio de Gram negativas. A concentração de protozoários foi 51,5 no grupo pasto e $47,5 \times 10^{4} / \mathrm{ml}$ no grupo pasto e concentrado com ligeira dominância de protozoários pequenos; a motilidade foi melhor em banhomaria que em temperatura ambiente, refrigerado ou congelado, respectivamente. A viabilidade do fluido ruminal coletado de bovinos recém abatidos é influenciada pela alimentação in vivo, mas as alterações decorrentes do tempo e da temperatura de estocagem são mais marcantes. O fluido ruminal é viável por nove horas quando estocado em banho-maria $\left(38^{\circ} \mathrm{C}\right)$, duas horas sob temperatura ambiente e mostra-se inadequado após refrigeração ou congelamento.

Palavras-chave: Estocagem. Fluido ruminal. Microbiota. Rumen. Transfaunação.

\section{Introduction}

Ruminants and ruminal microorganisms have a clear symbiotic relationship in which the ruminants provide a habitat for the growth of the microorganisms that, in turn, provide acids produced by fermentation and microbial proteins (KESSEL; RUSSELL, 1996; KHAFIPOUR et al., 2009). Protozoans comprise $40-80 \%$ of the ruminal microbial biomass and include numerous species. Ciliated protozoans play a key role in ruminant nutrition because they digest fiber, proteins, and carbohydrates; assist in energy metabolism; assimilate soluble carbohydrates; and produce volatile fatty acids (NOGUEIRA FILHO et al., 2000; MANELLA; LOURENÇO, 2004; RISPOLI et al., 2009).

Drastic changes in ruminal $\mathrm{pH}$ lead to the death of most of the microorganisms present in the rumen. In such cases, transfaunation, that is, the transference of ruminal fluid from a healthy animal to a sick one, is recommended (SILVA et al., 2005), especially for the treatment of digestive problems of food origin and after rumenotomy to reset the microbiota removed during surgery (SOUZA, 1990;BORGES et al., 2002; SILVA et al., 2005; CÂMARA et al., 2009). Conservation of ruminal fluid is still a challenge, and transfaunation using quality rumen fluid can be decisive for the life of sick ruminants (SOUZA, 1990).

To perform transfaunation, both animals are ideally adapted to the same diet (TAJIMA et al., 2000). However, it is not viable to maintain fistulated animals for this purpose (OLIVEIRA et al., 1999), so a frequently adopted alternative is to use rumen fluid from a freshly slaughtered animal. It is preferable that the rumen fluid is supplied as soon as possible after collection to avoid changes due to cooling and exposure to air, which alter the protozoal and bacterial activities and cause changes in $\mathrm{pH}$ (JONES; SMITH, 2009). Besides, use of the ruminal fluid of freshly slaughtered animals allows the removal of a greater amount of fluid at one time and avoids multiple samplings from the same animal, which results in a significant reduction in the number of protozoans (BARBOSA et al., 2003).

In many cases, it is necessary to repeat transfaunation after a few hours by using the same collected ruminal fluid (CAMARA et al., 2009), and, then, it is essential to check its viability. The aim of this study was to evaluate the viability of extracorporeal rumen fluid of cattle with respect to feed, temperature, and storage time.

\section{Material and Methods}

Ruminal fluid was collected from 14 healthy and freshly slaughtered adult cattle. Seven animals were fed exclusively on pasture, and seven on pasture and concentrate. From each bovine, $1000 \mathrm{ml}$ of ruminal fluid was collected and packaged in plastic bottles, which were immediately closed to avoid contact with air. The samples were transported in a cooler $\left(36^{\circ} \mathrm{C}\right)$, and each sample was divided into four subgroups (250 $\mathrm{ml}$ each) according to storage temperature: water bath at $38^{\circ} \mathrm{C}$, ambient temperature from $15^{\circ} \mathrm{C}$ to $25^{\circ} \mathrm{C}$, cooling between 2 and $4^{\circ} \mathrm{C}$, and freezing from $-18^{\circ} \mathrm{C}$ to $-16^{\circ} \mathrm{C}$. 
The physical, chemical, and microbiological assessments were performed according to the methodology described by Dirksen (1993). Color, odor, and consistency of the fluid were physically evaluated. The chemical evaluation included $\mathrm{pH}$, methylene blue reduction time, and concentration of chloride in the supernatant obtained after centrifuging $10 \mathrm{ml}$ of the sample fluid at $3000 \mathrm{rpm}$ for $15 \mathrm{~min}$; a photocolorimeter and commercial kit were used (Cloretos Liquiform, Labtest Diagnóstica, Lagoa Santa, MG, Brazil). One drop of the ruminal fluid was used for the microbiological evaluation witha microscope $(40 \times$ to $100 \times)$, and the viability score $(0$, absence of viable protozoa; 1 , up to $30 \%$ viable protozoa; 2 , between $30 \%$ and $70 \%$ viable protozoa; 3,over $70 \%$ viable protozoa), motility ( 0 , no; 1 , low; 2 , moderate; 3 , normal; ideal values higher than 1.75); and percentage of small, medium, and large protozoans were recorded. The counting of the protozoans was performed using a FuchsRosenthal chamber. The bacterial population was evaluated using Gram-stained smears.

The evaluations were performed using fresh samples (until $30 \mathrm{~min}$ ) and samples collected after 2 h, 4 h, 6 h, 9 h, 12 h, 18 h, and 24 h. The analysis was finished before $48 \mathrm{~h}$ when absence of viable microorganisms was observed by an increase in methylene-blue reduction time (cutoff, $15 \mathrm{~min}$ ) or absence of viable protozoans. The chloride concentration, bacterial counts, and size of the protozoans were recorded only at fresh. The parametric data were analyzed using oneway analysis of variance, followed by StudentNewman-Keuls test, and the non-parametric data using the Kruskal-Wallis test with $\mathrm{P}<0.05$.

\section{Results and Discussion}

The physical evaluation of fresh ruminal fluid was normal according to the standards cited by Dirksen (1993) and Feitosa (2008). Changes in these characteristics occurred primarily in the samples that were cooled, followed by those maintained at ambient temperature and final lyin the water bath. Under frozen conditions, no changes in the physical parameters of the samples were observed; however, the samples were discarded after $2 \mathrm{~h}$ because of bacterial and protozoal inactivity.

In the pasture group, $57.1 \%$ had a greenish ruminal liquid and $42.9 \%$, olive, where as, in the pasture and concentrate group, $57.1 \%$ had a light brown ruminal liquid and $42.9 \%$, greenish brown; these findings were normal (BARBOSA et al., 2003; ZILIO et al., 2008). Over time, the samples became dark, and this change in color was due to protozoal inactivity and putrefaction of the fluid (SOUZA et al., 2009). At ambient temperature, these changes occurred after $6 \mathrm{~h}$ in the samples from the pasture and concentrate group and after $9 \mathrm{~h}$ in those from the pasture group. The cooled samples from the pasture and pasture and concentrate groups changed color after $6 \mathrm{~h}$. In water bath, these changes occurred after $12 \mathrm{~h}$ in the samples from the pasture and pasture and concentrate groups.

The fresh rumen fluid samples from all the animals were slightly viscous and aromatic, which are normal characteristics (SOUZA et al., 2009; BARBOSA et al., 2003; RODRIGUES et al., 2013). The viscous ruminal fluid indicates contamination by saliva, and absence of viscosity indicates prolonged fasting and microbial inactivity (FEITOSA, 2008). The odor is acidic when there is a lot of lactic acid, and it becomes repellant if there is putrefaction (ZILIO et al., 2008). Subsequently, the samples became less viscous with unpleasant odor. The water-bath samples of the pasture group changed in consistency and odor after $12 \mathrm{~h}$, where as those of the pasture and concentrate group showed changes after $6 \mathrm{~h}$, when $14.3 \%$ and $42.9 \%$ of the samples showed low viscosity and acidic odor, respectively. Changes in the samples from the pasture group at ambient temperature and cooled were observed after $9 \mathrm{~h}$ and $6 \mathrm{~h}$, respectively, where as these changes occurred after 6 hin the samples from the pasture and concentrate group. Borges et al. (2002) also observed changes in the color, odor, 
and consistency of bovine rumen fluid maintained in a thermos for $12 \mathrm{~h}$.

Diet interferes directly with ruminal $\mathrm{pH}$ (MOREIRA et al., 2009; DOMINGUES et al., 2010), which ranges from 5.5 to 7.4 ; this value is also influenced by fasting and method of collection of ruminal fluid (BARBOSA et al., 2003). The $\mathrm{pH}$ of fresh ruminal fluid was 7.5 in the pasture group and 6.4 in the pasture and concentrate group (Table 1), which is standard, including higher $\mathrm{pH}$ in animals fed exclusively at the pasture (OLIVEIRA et al., 1993; ZILIO et al., 2008; MOREIRA et al., 2009; SOUZA et al., 2009). The pre-slaughter fasting must have also contributed to the increase in $\mathrm{pH}$ because of contamination by alkaline saliva (DIRKSEN, 1993; FEITOSA, 2008).

Table 1. $\mathrm{pH}$ and methylene blue reduction time ( $\mathrm{min}$ ) (average $\pm \mathrm{SD}$ ) of the ruminal fluid of cattle fed in vivo with pasture (GP) or pasture and concentrate (GPC) stored in a water bath (WBs) or at ambient temperature (ATs) or cooling (Cs) or freezing (Fs) and evaluated at fresh time (TF) and for $24 \mathrm{~h}$ after collection.

\begin{tabular}{|c|c|c|c|c|c|c|c|c|c|}
\hline & & $\mathrm{TF}$ & $\mathrm{T} 2 \mathrm{~h}$ & $\mathrm{~T} 4 \mathrm{~h}$ & T6h & $\mathrm{T} 9 \mathrm{~h}$ & $\mathrm{~T} 12 \mathrm{~h}$ & $\mathrm{~T} 18 \mathrm{~h}$ & $\mathrm{~T} 24 \mathrm{~h}$ \\
\hline \multirow{10}{*}{$\frac{T}{2}$} & & \multicolumn{8}{|c|}{ GP } \\
\hline & WBs & $7.5 \pm 0.4^{\mathrm{aA}}$ & $7.7 \pm 0,4^{\mathrm{aA}}$ & $7.8 \pm 0.4^{\mathrm{bA}}$ & $7.8 \pm 0.5^{\mathrm{bA}}$ & $7.7 \pm 0.5^{\mathrm{aA}}$ & $7.5 \pm 0.5^{\mathrm{aA}}$ & $7.4 \pm 0.5^{\mathrm{aA}}$ & $7.2 \pm 0.4^{\mathrm{aA}}$ \\
\hline & ATs & $7.5 \pm 0.4^{\mathrm{aA}}$ & $7.7 \pm 0,4^{\mathrm{aA}}$ & $7.8 \pm 0.4^{\mathrm{bA}}$ & $7.8 \pm 0.5^{\mathrm{bA}}$ & $7.7 \pm 0.6^{\mathrm{bA}}$ & - & - & - \\
\hline & Cs & $7.5 \pm 0.4^{\mathrm{aA}}$ & $7.7 \pm 0,4^{\mathrm{aA}}$ & $7.8 \pm 0.5^{\mathrm{bA}}$ & - & - & - & - & - \\
\hline & Fs & $7.5 \pm 0.4^{\mathrm{aA}}$ & $7.7 \pm 0,4^{\mathrm{bA}}$ & - & - & - & - & - & - \\
\hline & & \multicolumn{8}{|c|}{ GPC } \\
\hline & WBs & $6.4 \pm 0.4^{\mathrm{aA}}$ & $6.1 \pm 0.5^{\mathrm{aA}}$ & $6.2 \pm 0.6^{\mathrm{aA}}$ & $6.1 \pm 0.6^{\mathrm{aA}}$ & $6.2 \pm 0.7^{\mathrm{aA}}$ & $6.2 \pm 0.8^{\mathrm{aA}}$ & $6.1 \pm 0.8^{\mathrm{bA}}$ & $5.9 \pm 0.8^{\mathrm{bA}}$ \\
\hline & ATs & $6.4 \pm 0.4^{\mathrm{aA}}$ & $6.3 \pm 0.5^{\mathrm{aAC}}$ & $6.3 \pm 0.5^{\mathrm{aA}}$ & $6.3 \pm 0.5^{\mathrm{aA}}$ & - & - & - & - \\
\hline & Cs & $6.4 \pm 0.4^{\mathrm{aA}}$ & $6.4 \pm 0.5^{\mathrm{aB}}$ & $6.4 \pm 0.6^{\mathrm{aA}}$ & $6.3 \pm 0.6^{\mathrm{aB}}$ & - & - & - & - \\
\hline & Fs & $6.4 \pm 0.4^{\mathrm{aA}}$ & $6.5 \pm 0.5^{\mathrm{aBC}}$ & $6.3 \pm 0.5^{\mathrm{aA}}$ & - & - & - & - & - \\
\hline \multirow{10}{*}{ 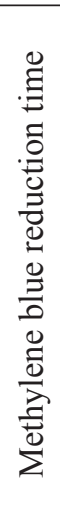 } & & \multicolumn{8}{|c|}{ GP } \\
\hline & WBs & $2.4 \pm 0.7^{\mathrm{aA}}$ & $2.4 \pm 0.9^{\mathrm{aA}}$ & $3.1 \pm 0.9^{\mathrm{aA}}$ & $3.7 \pm 0.8^{\mathrm{aA}}$ & $4.6 \pm 0.8^{\mathrm{bA}}$ & $6.0 \pm 1.2^{\mathrm{bA}}$ & $7.6 \pm 2.2^{\mathrm{bA}}$ & $11.6 \pm 2.6^{\mathrm{bA}}$ \\
\hline & ATs & $2.4 \pm 0.7^{\mathrm{aA}}$ & $4.0 \pm 1.9^{\mathrm{aA}}$ & $5.6 \pm 2.2^{\mathrm{bB}}$ & $7.2 \pm 3.5^{\mathrm{bB}}$ & $9.0 \pm 3.0^{\mathrm{bB}}$ & - & - & - \\
\hline & Cs & $2.4 \pm 0.7^{\mathrm{aA}}$ & $5.7 \pm 2.1^{\mathrm{bA}}$ & $9.4 \pm 2.0^{\mathrm{bC}}$ & - & - & - & - & - \\
\hline & Fs & $2.4 \pm 0.7^{\mathrm{aA}}$ & $13.2 \pm 2.6^{\mathrm{bB}}$ & - & - & - & - & - & - \\
\hline & & \multicolumn{8}{|c|}{ GPC } \\
\hline & WBs & $1.9 \pm 0.5^{\mathrm{aA}}$ & $2.0 \pm 0.6^{\mathrm{aA}}$ & $2.7 \pm 0.7^{\mathrm{aA}}$ & $3.2 \pm 0.8^{\mathrm{aA}}$ & $3.8 \pm 0.5^{\mathrm{bA}}$ & $4.9 \pm 0.7^{\mathrm{bA}}$ & $7.8 \pm 1.6^{\mathrm{bA}}$ & $11.5 \pm 2.5^{\mathrm{bA}}$ \\
\hline & ATs & $1.9 \pm 0.5^{\mathrm{aA}}$ & $3.6 \pm 2.2^{\mathrm{aA}}$ & $5.6 \pm 3.2^{\mathrm{bAB}}$ & $7.7 \pm 5.0^{\mathrm{bA}}$ & - & - & - & - \\
\hline & Cs & $1.9 \pm 0.5^{\mathrm{aA}}$ & $4.8 \pm 2.1^{\mathrm{aA}}$ & $8.5 \pm 4.4^{\mathrm{bB}}$ & - & - & - & - & - \\
\hline & Fs & $1.9 \pm 0.5^{\mathrm{aA}}$ & $12.7 \pm 3.9^{\mathrm{bB}}$ & $14.9 \pm 0.3^{\mathrm{bC}}$ & - & - & - & - & - \\
\hline
\end{tabular}

Lower case letters different indicate values difference in time (line) $(\mathrm{p}<0,05)$

Capital letters different indicate values difference betwen groups (column) $(\mathrm{p}<0,05)$.

In the pasture and concentrate group, a significant reduction in $\mathrm{pH}$ was observed as a function of time and temperature storage. The $\mathrm{pH}$ reduction due to the loss of anaerobic conditions in the rumen fluid during storage promotes the reaction of ammonia with oxygen and results in the formation of ammonium hydroxide, which decreases pH (OLIVEIRA et al., 1993). Furthermore, excessive production of lactic acid due to putrefaction and decomposition of proteins occurs (BORGES et al., 2002). 
The methylene blue reduction time of the fresh ruminal fluid was 2.35 in the pasture group and 1.86 in the pasture and concentrate group. This test is used to determine the time required for the population of bacteria to perform anaerobic fermentative metabolism (DIRKSEN, 1993) and is considered normal up to $6 \mathrm{~min}$ (BARBOSA et al. 2003). Cattle that receive the concentrate show increased methylene blue reduction time because the non structural carbohydrates are digested more quickly (DIRKSEN, 1993; SOUZA et al., 2009). Over time, the methylene blue reduction value is expected to increase (SOUZA et al., 1990; BORGES et al., 2002), but temperature storage also influences this parameter. In both groups, methylene blue reduction values less than 6 min were observed until after 2 $\mathrm{h}$ for the frozen samples, after $4 \mathrm{~h}$ for the cooled samples, after $6 \mathrm{~h}$ for the ambient temperature samples; however, in the water bath the values were observed until after $12 \mathrm{~h}$ in the pasture group and until after $18 \mathrm{~h}$ in the pasture and concentrate group (Table 1).Surely, this was influenced by the viability of the microorganisms.

The chloride content in the rumen fluid is influenced by the reflux of food contents from the abomasum and intestines (CÂMARA et al., 2009; SILVA FILHO et al., 2010) and should be between 15 and $30 \mathrm{mEq} / 1$ (DIRKSEN, 1993). The chloride content was $15.7 \pm 5.8 \mathrm{mEq} / 1$ in the pasture group and $16.3 \pm 3.6 \mathrm{mEq} / 1$ in the pasture and concentrate group, which confirmed the results of Barbosa et al. (2003).

The gram-negative bacteria were predominant, which is a normal finding (DIRKSEN, 1993; BARBOSA et al., 2003). However, ruminants that receive a high-carbohydrate diet can show reduction in $\mathrm{pH}$, resulting in the proliferation of Streptococcus bovis and Lactobacillus sp. that are tolerant to low $\mathrm{pH}$ and, thus, predominance of gram-negative bacteria (MIRANDA NETO et al., 2005; MOREIRA et al., 2009).

The number of protozoa can oscillate according to the received diet, method of collection, time of the year, and time of feeding (OLIVEIRA et al., 1999; NOGUEIRA FILHO et al., 2000; BARBOSA et al., 2003). The average concentration of protozoa was $51.5 \pm 8.8 \times 10^{4} / \mathrm{ml}$ in the pasture group and $47.5 \pm 8.8$ $\times 10^{4} / \mathrm{ml}$ in the pasture and concentrate group, and the values were higher than those observed in other studies in which collection was performed via probe (OLIVEIRA et al., 1999; MANELLA; LOURENÇO, 2004). Barbosa et al. (2003) found that a higher volume of ruminal fluid with greater concentration of viable protozoacan be collected from freshly slaughtered animals.

Motility was ideal when the score was higher than 1.75; therefore, the cooled or frozen samples were serviceable only when fresh in both groups (Table 2). At ambient temperature, the motility was ideal until after $2 \mathrm{~h}$ in the pasture group samples and until after $4 \mathrm{~h}$ in the pasture and concentrate group, which is consistent with the results reported by Souza (1990). In the water bath, the samples were ideal until after $9 \mathrm{~h}$ in both groups, which is similar to the results of Borges et al. (2002).

A slight predominance of small protozoa was observed in the pasture group $(39.9 \pm 13.1 \%)$ and pasture and concentrate group $(34.7 \pm 3.6 \%)$, followed by medium-sized protozoa $(32.2 \pm 4.1 \%$ and $32.7 \pm 1.8 \%$, respectively) and largesized protozoa $(27.9 \pm 17.0 \%$ and $32.7 \pm 1.8 \%$, respectively); these results are consistent with those of Barbosa et al. (2003) and Miranda Neto et al. (2005). During storage, the small protozoa were the first to lose viability in both groups, while the large protozoa remained viable for a longer period. This finding contradicts those of other studies in which the large protozoa lost viability early (DIRKSEN, 1993; BORGES et al., 2002; FEITOSA, 2008). 
Table 2. Viability and motility of protozoans (average \pm SD) in the ruminal fluid of cattle fed in vivo with pasture (GP) or pasture and concentrate (GPC) stored in a water bath (WBs) or at ambient temperature (ATs) or cooling (Cs) or freezing (Fs) and evaluated at fresh time (TF) and for $24 \mathrm{~h}$ after collection.

\begin{tabular}{|c|c|c|c|c|c|c|c|c|c|}
\hline & & $\mathrm{TF}$ & $\mathrm{T} 2 \mathrm{~h}$ & $\mathrm{~T} 4 \mathrm{~h}$ & T6h & T9h & $\mathrm{T} 12 \mathrm{~h}$ & $\mathrm{~T} 18 \mathrm{~h}$ & $\mathrm{~T} 24 \mathrm{~h}$ \\
\hline \multirow{10}{*}{ 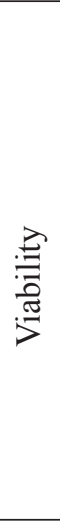 } & & \multicolumn{8}{|c|}{ GP } \\
\hline & WBs & $2.7 \pm 0.5^{\mathrm{aA}}$ & $2.7 \pm 0.5^{\mathrm{aA}}$ & $2.3 \pm 0.5^{\mathrm{aA}}$ & $2.0 \pm 0.6^{\mathrm{aA}}$ & $1.6 \pm 0.5^{\mathrm{aA}}$ & $1.1 \pm 0.4^{\mathrm{bA}}$ & $1.0 \pm 0.6^{\mathrm{bA}}$ & - \\
\hline & ATs & $2.7 \pm 0.5^{\mathrm{aA}}$ & $2.3 \pm 0.8^{\mathrm{aA}}$ & $1.4 \pm 0.5^{\mathrm{aAB}}$ & $1.1 \pm 0.4^{\mathrm{bB}}$ & $0.4 \pm 0.5^{\mathrm{bB}}$ & - & - & - \\
\hline & Cs & $2.7 \pm 0.5^{\mathrm{aA}}$ & $1.7 \pm 0.6^{\mathrm{aAB}}$ & $0.6 \pm 0.8^{\mathrm{bB}}$ & - & - & - & - & - \\
\hline & Fs & $2.7 \pm 0.5^{\mathrm{aA}}$ & $0.6 \pm 0.8^{\mathrm{bB}}$ & - & - & - & - & - & - \\
\hline & & \multicolumn{8}{|c|}{ GPC } \\
\hline & WBs & $2.6 \pm 0.5^{\mathrm{aA}}$ & $2.4 \pm 0.5^{\mathrm{aA}}$ & $2.0 \pm 1.0^{\mathrm{aA}}$ & $1.9 \pm 0.9^{\mathrm{aA}}$ & $1.7 \pm 0.8^{\mathrm{aA}}$ & $1.4 \pm 0.8^{\mathrm{aA}}$ & - & - \\
\hline & ATs & $2.6 \pm 0.5^{\mathrm{aA}}$ & $2.0 \pm 1.0^{\mathrm{aA}}$ & $1.7 \pm 1.0^{\mathrm{aB}}$ & $1.1 \pm 0.9^{\mathrm{aA}}$ & - & - & - & - \\
\hline & Cs & $2.6 \pm 0.5^{\mathrm{aA}}$ & $1.9 \pm 0.9^{\mathrm{aA}}$ & $1.0 \pm 0.6^{\mathrm{bBC}}$ & - & - & - & - & - \\
\hline & Fs & $2.6 \pm 0.5^{\mathrm{aA}}$ & $1.6 \pm 0.8^{\mathrm{aA}}$ & $0.6 \pm 0.5^{\mathrm{bC}}$ & - & - & - & - & - \\
\hline \multirow{10}{*}{ 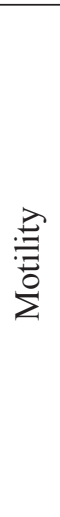 } & & \multicolumn{8}{|c|}{ GP } \\
\hline & WBs & $2.6 \pm 0.5^{\mathrm{aA}}$ & $2.4 \pm 0.5^{\mathrm{aA}}$ & $2.1 \pm 0.4^{\mathrm{aA}}$ & $2.0 \pm 0.1^{\mathrm{aA}}$ & $1.9 \pm 0.4^{\mathrm{bA}}$ & $1.1 \pm 0.4^{\mathrm{bA}}$ & $1.0 \pm 0.6^{\mathrm{bA}}$ & - \\
\hline & ATs & $2.6 \pm 0.5^{\mathrm{aA}}$ & $2.3 \pm 0.5^{\mathrm{aA}}$ & $1.4 \pm 0.5^{\mathrm{aAB}}$ & $1.3 \pm 0.5^{\mathrm{bB}}$ & $0.4 \pm 0.5^{\mathrm{bB}}$ & - & - & - \\
\hline & $\mathrm{Cs}$ & $2.6 \pm 0.5^{\mathrm{aA}}$ & $1.4 \pm 0.5^{\mathrm{aAB}}$ & $0.4 \pm 0.5^{\mathrm{bB}}$ & - & - & - & - & - \\
\hline & Fs & $2.6 \pm 0.5^{\mathrm{aA}}$ & $0.4 \pm 0.5^{\mathrm{bA}}$ & - & - & - & - & - & - \\
\hline & & \multicolumn{8}{|c|}{ GPC } \\
\hline & WBs & $2.4 \pm 0.5^{\mathrm{aA}}$ & $2.4 \pm 0.5^{\mathrm{aA}}$ & $2.3 \pm 0.5^{\mathrm{bA}}$ & $1.9 \pm 0.9^{\mathrm{bA}}$ & $1.9 \pm 0.9^{\mathrm{bA}}$ & $1.3 \pm 0.8^{\mathrm{bA}}$ & $0.9 \pm 0.9^{\mathrm{bA}}$ & - \\
\hline & ATs & $2.4 \pm 0.5^{\mathrm{aA}}$ & $2.4 \pm 0.5^{\mathrm{aA}}$ & $1.9 \pm 0.7^{\mathrm{aAB}}$ & $1.3 \pm 0.9^{\mathrm{aA}}$ & - & - & - & - \\
\hline & Cs & $2.4 \pm 0.5^{\mathrm{aA}}$ & $1.6 \pm 0.8^{\mathrm{aA}}$ & $1.1 \pm 0.7^{\mathrm{bAB}}$ & - & - & - & - & - \\
\hline & Fs & $2.4 \pm 0.5^{\mathrm{aA}}$ & $1.4 \pm 0.5^{\mathrm{bA}}$ & $0.6 \pm 0.5^{\mathrm{bB}}$ & - & - & - & - & - \\
\hline
\end{tabular}

Viability scores: 0 , absence of viable protozoa; 1 , up to $30 \%$ viable protozoa; 2 , between $30 \%$ and $70 \%$ viable protozoa; 3 , over $70 \%$ viable protozoa

Motility scores: 0 , no; 1 , low; 2 , moderate; 3 , normal; ideal values higher than 1.75

Lowercase letters different indicate values difference in time $(\mathrm{p}<0,05)$

Capital letters different indicate values difference betwen groups (column) $(p<0,05)$.

The analysis of the rumen fluid of cattle fed exclusively on pasture and supplemented with concentrate and slaughtered recently proved interesting, and the physical, chemical, and microbiological viabilities of the fluid samples subjected to different storage temperatures were verified. Our findings will help to ensure that veterinarians use suitable rumen fluid for transfaunation.

\section{Conclusion}

The viability of ruminal fluid collected from freshly slaughtered cattle is influenced by the food provided in vivo; however, changes as a function of time and storage temperature are more remarkable. The rumen fluid is viable for up to $9 \mathrm{~h}$ when stored in a water bath $\left(38^{\circ} \mathrm{C}\right)$ and $2 \mathrm{~h}$ at ambient temperature, and it was observed to be nonviable when subjected to cooling or freezing.

\section{Bioethics and Biosecurity Committee Approval}

This study was approved by the Ethics Committee on Animal Use - UFPR/Palotina (n. 33/2010). 


\section{References}

BARBoSA, J. D.; ÁVILA, S. D.; DIAS, R. D. C.; PFEIFER, I. B.; OLIVEIRA, C. D. Estudo comparativo de algumas provas funcionais do fluido ruminal e de metabólitos sangüíneos de bovinos e bubalinos. Pesquisa Veterinária Brasileira, Seropédica, v. 23, n. 1, p. 33-37, 2003.

BORGES, N. C.; SILVA, L. A. F.; FIORAVANTI, M. C. S.; DA CUNHA, P. H. J.; MORAES, R. R.; GUIMARÃES, P. L.; MARTINS, M. E. P. Avaliação de suco ruminal de bovinos a fresco e após 12 horas de conservação. Ciência Animal Brasileira, Goiânia, v. 3, n. 2, p. 57-63, 2002.

CÂMARA, A. C. L.; AFONSO, J. A. B.; COSTA, N. A.; MENDONÇA, C. L. de; SOUZA, M. I. de. Compactação primária do abomaso em 14 bovinos no Estado de Pernambuco. Pesquisa Veterinária Brasileira, Seropédica, v. 29, n. 5, p. 387-394, 2009.

DIRKSEN, G. Sistema digestivo. In.: DIRKSEN, G.; GRÜNDER, H.D.; STÖBER, M. Rosemberger - exame clínico dos bovinos. 3. ed. Rio de Janeiro: GuanabaraKoogan, 1993. p. 166-228.

DOMINGUES, A. R.; SILVA, L. D. F.; RIBEIRO, E. L. A.; CASTRO, V. S.; BARBOSA, M. A. A. F.; MORI, R. M.; VIEIRA, M. T. L.; SILVA, J. A. O. Consumo, parâmetros ruminais e concentração de uréia plasmática em novilhos alimentados com diferentes níveis de torta de girassol em substituição ao farelo de algodão. Semina: Ciências Agrárias, Londrina, v. 31, n. 4, p. 1059-1070, 2010.

FEITOSA, F. L. F. Semiologia do sistema digestivo de ruminantes. In.: Semiologia veterinária: a arte o diagnóstico: cães, gatos equinos, ruminantes e silvestres. 2. ed. São Paulo: Roca, 2008. p. 108-138.

JONES, S. L.; SMITH, B. P. Diseases of the alimentary tract. In: SMITH, B. P. Large animal internal medicine. 4. ed. St. Louis: Mosby Elsevier, 2009. p. 667-892.

KESSEL, J. A. S.; RUSSELL, J. B. The effect of pH on ruminal methanogenesis. FEMS Microbiology Ecology, Paris, v. 20, n. 4, p. 205-210, 1996.

KHAFIPOUR, E.; LI, S.; PLAIZIER, J. C.; KRAUSE, D. O. Rumen microbiome composition determined using two nutritional models of subacute ruminal acidosis. Applied and Environmental Microbiology, Washington, v. 75, n. 22, p. 7115-7124, 2009.

MANELLA, M. Q.; LOURENÇO, A. J. População de protozoários ciliados no rúmen de bovinos nelore em pastos de Brachiaria brizantha Marandu recebendo suplemento protéico ou com livre acesso a banco de proteína de Leucaena leucocephala nas diferentes estações do ano. Boletim de Indústria Animal, Nova Odessa, v. 61, n. 1, p. 1-11, 2004.

MIRANDA NETO, E. G.; AFONSO, J. A. B.; MENDONÇA, C. L.; ALMEIDA, M. Z. Estudo clínico e características do suco ruminal de caprinos com acidose láctica induzida experimentalmente. Pesquisa Veterinária Brasileira, Seropédica, v. 25, n. 2, p. 73-78, 2005.

MOREIRA, P. C.; MENDONÇA, A. C.; MARTINS, A. F.; CAMARGO, R. de; SOUZA, P. R. de; DUTRA, A. R.; GRANDSIRE, C. Avaliação do $\mathrm{pH}$ do fluido ruminal de vacas leiteiras alimentadas com diferentes proporções concentrado: volumoso. Estudos, Goiânia v. 36, n. 6, p. 1201-1218, 2009.

NOGUEIRA FILHO, J. C. M.; OLIVEIRA, M. E. M. de; SOUZA ABLAS, D. de; TITTO, E. A. L.; TOLEDO, L. R. A. de; OLIVEIRA, T. S. B. M. de. Fauna ciliada do rúmen de zebuínos e bubalinos em Pirassununga, São Paulo, Sudeste do Brasil. Acta Scientiarum. Animal Sciences, Maringá, v. 22, n. 1, p. 663-668, 2000.

OLIVEIRA, M. D. S. D.; SAMPAIO, A. A. M.; VIEIRA, P. D. F.; FREITAS, J. C. M. D.; SHOCKENITURRINO, R. P. Efeito de métodos de coleta de fluido ruminal em bovinos sobre alguns parâmetros ruminais e microbiológicos. Pesquisa Agropecuária Brasileira, Brasília, v. 34, n. 5, p. 867-871, 1999.

OLIVEIRA, M. D. S.; VIEIRA, P. F.; SOUZA, A.; BANZATO, D. Efeito de métodos de coleta de fluido ruminal sobre a digestibilidade in vitro de alguns nutrientes de ração para bovinos. Revista Brasileira de Zootecnia, Viçosa, v. 22, n. 5, p. 794-800, 1993.

RÍSPOLI, T. B.; RODRIGUES, I. L.; MARTINS NETO, R. G.; KAZAMA, R.; PRADO, O. P. P.; ZEOULA, L. M.; ARCURI, P. B. Protozoários ciliados do rúmen de bovinos e bubalinos alimentados com dietas suplementadas com monensina ou própolis. Pesquisa Agropecuária Brasileira, Brasília, v. 44, n. 1, p. 92-97, 2009.

RODRIGUES, M.; DESCHK, M.; SANTOS, G. G.; PERRI, S. H.; MERENDA, V. R.; HUSSNI, C. A.; RODRIGUES, C. A. Avaliação das características do líquido ruminal, hemogasometria, atividade pedométrica e diagnóstico de laminite subclínica em vacas leiteiras. Pesquisa Veterinária Brasileira, Seropédica, v. 33, p. 99106, 2013. Suplemento 1.

SILVA FILHO, A. P.; AFONSO, J. A. B.; ALMEIDA SOUZA, J. C. de; AZEVEDO COSTA, N. de; MENDONÇA, C. L. Análise clínica e patológica em 20 casos de intussuscepção em bovinos. Veterinária $e$ Zootecnia, Botucatu, v. 17, n. 3, p. 421-430, 2010. 
SILVA, D. L. A. F.; SILVA, E. G. F. S. Rumenotomia em bovinos: uso da paramentação e de oxitetraciclina parenteral na profilaxia de complicações pós-operatórias. Ciência Rural, Santa Maria, v. 35, n. 3, p. 611-617, 2005.

SOUZA, P. M. Conservação de suco de rúmem: avaliação das características macroscópicas, microscópicas e de determinadas provas funcionais. 1990. Dissertação (Mestrado em Medicina Veterinária) - Curso de PósGraduação em Medicina Veterinária. Universidade Federal Rural de Pernambuco, Recife.

SOUZA, W. A.; RIBEIRO, T. B.; GODOY, R. C. S.; SANTOS, D. E.; DE PAULA, F. C.; BOCARDO, M.; SACCO, S. R.; AVANZA, M.; BATISTA, J. C.; ROSA, E. P.; PEREIRA, E. C. Estudo comparativo de parâmetros do líquido ruminal em bovinos da raça Jersey a pasto e confinados na região de garça - SP. Revista Científica Eletrônica de Medicina Veterinária, São Paulo, v. 13, n. 13, p. 1-7, 2009.

TAJIMA, K.; ARAI, S.; OGATA, K.; NAGAMINE, T.; MATSUI, H.; NAKAMURA, M.; BENNO, Y. Rumen bacterial community transition during adaptation to highgrain diet. Anaerobe, London, v. 6, n. 5, p. 273-284, 2000.

ZILIO, R. S.; CRUZ, E. D. V.; ANDRADE JÚNIOR, J. P. D.; MERLINI, G. P.; DUQUE, P. V. T.; SACCO, S. R. Análise do liquido ruminal - revisão de literatura. Revista Científica Eletrônica de Medicina Veterinária, São Paulo, v. 11, n. 11, p. 1-6, 2008. 